\title{
Clonality testing: teamwork by pathologist and molecular biologist
}

\author{
An introduction to the clonality issue of the Journal of Hematopathology
}

\author{
J. Han van Krieken • Jose Cabeçadas • \\ Patricia J. T. A. Groenen
}

Received: 12 February 2012 / Accepted: 12 February 2012 / Published online: 25 February 2012

(C) Springer-Verlag 2012

Clonality testing is a mature technique that is a reliable tool in the routine diagnostics of lymphoproliferations [1]. Almost all lymphomas are clonal [2,3], and the majority of reactive lymphoproliferations are polyclonal [4]. Although the standard method, using the full program of antigen receptors, is now available for almost a decade [5], there is still great need for teaching and exchange of experience. This is due to the fundamental different principles that form the basis of clonality testing as a molecular test, compared to other molecular tests in pathology. Most molecular tests deal with a pathological change in the DNA of a tumor. Examples are of course mutations and amplifications in oncogenes, translocations resulting in abnormal gene activity or even novel proteins. In all these situations, there are important quality issues and external quality assurance is mandatory [6-8]. In these tests the interaction of pathologists and molecular biologists should not be underestimated, but it is not in comparison with clonality testing. The main reason is that clonality testing is not dealing with pathological but rather physiological changes in the DNA.

It is well known that every mature $\mathrm{B}$ and $\mathrm{T}$ cell has a unique set of rearranged antigen receptor genes, unique in the sense that after a B or T cell is fully differentiated, it will start to proliferate in case the proper antigen is present resulting in small clones. The usefulness of clonality testing lies in the fact that reactive lesions have proliferations of

J. H. van Krieken $(\bowtie) \cdot$ P. J. T. A. Groenen

Department of Pathology,

Radboud University Nijmegen Medical Centre,

Nijmegen, The Netherlands

e-mail: J.vanKrieken@pathol.umcn.nl

J. Cabeçadas

Regional Centre of Oncology,

Lisbon, Portugal many different $\mathrm{B}$ and/or T cells, whereas a malignant lesion consists of the proliferation of a single B or T cell. It is therefore clear that in principle, a sensitive clonality test, in which rearranged antigen receptors are amplified, will detect every B and T cell, physiological or pathological. A sharp contrast with a test which aims at the detection of a pathological change: in case a mutation is found, it implies that the test is positive. In case a clonal B or T cell population is found, it implies only that there is indeed a clonal population. This result really has to be interpreted in the full pathological context of the lesion. And this can only be done by bringing the pathology (morphology and immunophenotype) and molecular biology together.

This special issue on clonality testing in Hematopathology assembles a series of articles that deal with problematic issues in applying this test and thus really is a teaching issue. In this editorial some of these issues are outlined stressing the importance of the interaction of the molecular biologists and the pathologists, each with her or his own expertise.

In general, a pathologist orders clonality testing in case a lesion is not clearly malignant or reactive. Some pathologists order clonality testing to confirm their diagnosis of a lymphoma. In such cases one may expect a relatively straightforward result of a clonality test: a dominant clonal result with a small background polyclonal pattern. Although this is helpful for building up experience, it is likely not cost-effective. In the more problematic cases, there can be multiple clones and one of these may be malignant. One therefore needs to combine all data to come to a conclusion.

Here we discuss some situations in which the interaction is critical.

- The composition of the tissue tested is important for interpretation of the clonality results. Normal germinal centers consist of one or a few B cells that are in the 
process of hypermutation and class switching. Germinal centers have a limited life span and more importantly consist of a limited number of physiological B-cell clones, varying from one to four. Since germinal centers may become large and may form the dominant B-cell population in a small sample, one can expect that a dominant clone can be detected using B-cell clonality testing. It is therefore mandatory that the tissue composition is checked before a sample is grinded for DNA extraction, in order to properly interpret the clonality result in case a single large germinal center is present in the sample. Hereby false interpretation of clonality can be prevented.

- In case a lesion has a follicular growth pattern, normally, BCL2 staining enables the distinction between reactive and neoplastic germinal centers. In the rare BCL2-negative follicular lymphoma, one may want to confirm the malignant nature of the lesion (which is often has no BCL2 rearrangement and thus translocation detection is not a good alternative) by clonality testing. It is important that in this situation the sample to be tested includes multiple follicular structures.

- The immunological background of a patient can be critical. In case of autoimmune disease, there is often oligoclonal B-cell hyperplasia. And often one of the clones is a bit larger than the others. The result of the clonality test is often an irregular polyclonal background with one or more reproducible dominant peaks, suggesting clonality in a background of oligoclonal B cells, which does not imply malignancy

- In case only a few B or T cells are present, one may expect smaller peaks, but also a lack of a polyclonal background due to the limited numbers of targets. This may lead to a false interpretation of a malignant clonal population, since such a pattern represents pseudoclonality.

- In rare cases all targets fail to amplify. In case a tissue contains many B cells but neither a clonal or polyclonal result is obtained, this should lead to the strong suggestion of a malignant population. One has to realize that this result is not really possible in a reactive lesion. Of course it is essential to exclude a technical failure. Even in lesions in which the great majority of cells belong to a single clone that goes undetected, in general, there are still some reactive B cells or plasma cells to be expected, and these should show up as a weak and most likely an irregular polyclonal pattern of rearrangements.

- The repertoire of lymphocytes, especially $\mathrm{T}$ lymphocytes, varies between organs. Especially in extranodal sites like the skin and the gut, the T-cell repertoire is limited so that a TCR clonality test on an extranodal tissue in which relatively few $\mathrm{T}$ cells are present can result in oligoclonality and even a clonal population may be seen.
In all these examples, the solution lies in combining pathology and clonality. The pathologist needs to carefully estimate the amount and percentage of $\mathrm{B}$ and $\mathrm{T}$ lymphocytes in the tissue that is used for DNA extraction, before and after the material is cut for the molecular test. This estimate needs to be taken into account when the results of clonality testing are interpreted. One needs to keep in mind though that PCR is not really a quantitative method and that several factors may result in preferred amplification of specific targets. Nevertheless, it is our experience at the yearly workshops that take place at the department of pathology of the Radboud University Nijmegen Medical Center that almost all problematic cases can be solved using the combined data from morphology, immunophenotyping, and the result of clonality testing, and of course the experience of both the pathologist and the molecular biologist.

In this issue of the Journal of Hematopathology, you will find several articles, discussing in depth some of the issues touched upon in this introduction. We hope that this issue will be a valuable guide in your use of clonality testing, to the benefit of the patients you care for.

\section{References}

1. van Krieken JH, Langerak AW, Macintyre EA, Kneba M, Hodges E, Sanz RG, Morgan GJ, Parreira A, Molina TJ, Cabeçadas J, Gaulard P, Jasani B, Garcia JF, Ott M, Hannsmann ML, Berger F, Hummel M, Davi F, Brüggemann M, Lavender FL, Schuuring E, Evans PA, White H, Salles G, Groenen PJ, Gameiro P, Pott Ch, Dongen JJ (2007) Improved reliability of lymphoma diagnostics via PCRbased clonality testing: report of the BIOMED-2 Concerted Action BHM4-CT98-3936. Leukemia 21:201-206

2. Evans PA, Pott Ch, Groenen PJ, Salles G, Davi F, Berger F, Garcia JF, van Krieken JH, Pals S, Kluin P, Schuuring E, Spaargaren M, Boone E, González D, Martinez B, Villuendas R, Gameiro P, Diss TC, Mills K, Morgan GJ, Carter GI, Milner BJ, Pearson D, Hummel M, Jung W, Ott M, Canioni D, Beldjord K, Bastard C, Delfau-Larue MH, van Dongen JJ, Molina TJ, Cabeçadas J (2007) Significantly improved PCR-based clonality testing in B-cell malignancies by use of multiple immunoglobulin gene targets. Report of the BIOMED-2 Concerted Action BHM4-CT98-3936. Leukemia 21:207-214

3. Brüggemann $M$, White $H$, Gaulard $P$, Garcia-Sanz R, Gameiro $P$, Oeschger S, Jasani B, Ott M, Delsol G, Orfao A, Tiemann M, Herbst H, Langerak AW, Spaargaren M, Moreau E, Groenen PJ, Sambade C, Foroni L, Carter GI, Hummel M, Bastard C, Davi F, Delfau-Larue MH, Kneba M, van Dongen JJ, Beldjord K, Molina TJ (2007) Powerful strategy for polymerase chain reaction-based clonality assessment in T-cell malignancies Report of the BIOMED2 Concerted Action BHM4 CT98-3936. Leukemia 21:215-221

4. Langerak AW, Molina TJ, Lavender FL, Pearson D, Flohr T, Sambade C, Schuuring E, Al Saati T, van Dongen JJ, van Krieken JH (2007) Polymerase chain reaction-based clonality testing in tissue samples with reactive lymphoproliferations: usefulness and pitfalls. A report of the BIOMED-2 Concerted Action BMH4CT98-3936. Leukemia 21:222-229

5. van Dongen JJ, Langerak AW, Brüggemann M, Evans PA, Hummel M, Lavender FL, Delabesse E, Davi F, Schuuring E, García-Sanz R, van Krieken JH, Droese J, González D, Bastard C, White HE, 
Spaargaren M, González M, Parreira A, Smith JL, Morgan GJ, Kneba M, Macintyre EA (2003) Design and standardization of PCR primers and protocols for detection of clonal immunoglobulin and T-cell receptor gene recombinations in suspect lymphoproliferations: report of the BIOMED-2 Concerted. Action BMH4-CT983936. Leukemia 17:2257-2317

6. van Krieken JH, Jung A, Kirchner T, Carneiro F, Seruca R, Bosman FT, Quirke P, Fléjou JF, Plato Hansen T, de Hertogh G, Jares P, Langner C, Hoefler G, Ligtenberg M, Tiniakos D, Tejpar S, Bevilacqua G, Ensari A (2008) KRAS mutation testing for predicting response to anti-EGFR therapy for colorectal carcinoma: proposal for an European quality assurance program. Virchows Arch 453:417-431
7. Dequeker E, Ligtenberg MJ, Vander Borght S, van Krieken JH (2011) Mutation analysis of KRAS prior to targeted therapy in colorectal cancer: development and evaluation of quality by a European external quality assessment scheme. Virchows Arch 459:155-160

8. Bellon E, Ligtenberg MJ, Tejpar S, Cox K, de Hertogh G, de Stricker K, Edsjö A, Gorgoulis V, Höfler G, Jung A, Kotsinas A, Laurent-Puig P, López-Ríos F, Hansen TP, Rouleau E, Vandenberghe P, van Krieken JJ, Dequeker E (2011) External quality assessment for KRAS testing is needed: setup of a European program and report of the first joined regional quality assessment rounds. Oncologist 16:467-478 